\title{
AN ARCTIC EQUIVALENT OF THE GRUMUSOL *
}

\author{
E. E. MacNamara* and J. C. F. Tedrow $\dagger$
}

\begin{abstract}
An arctic equivalent of the Grumusol is present in northern Alaska. The soil, high in montmorillonitic clays, has gilgai microrelief and a rather hard mineral surface. Considering freezing as being essentially a desiccating process operable at least once annually on these sites and evaporation exceeding precipitation, genesis of this soil appears to be similar to that of the Grumusols of the warm and temperate climates. Chemical and physical data are given.

RESUME. Un Equivalent arctique du Grumusol. Il existe dans le nord de l'Alaska un équivalent arctique du grumusol. Riche en montmorillonites, il présente un micro-relief en "gilgai" et une surface minérale plutôt dure. Si l'on considère que le gel est essentiellement un processus de dessication qui agit au moins une fois par an dans ces sites, où l'évaporation est plus importante que la précipitation, la genèse de ce sol paraît semblable a celle des grumusols des climats chauds et tempérés. Les auteurs présentent des données chimiques et physiques.
\end{abstract}

REZIUME. Arkticheskir Ekvivalent Grumusola. ArkticheskiY èkvivalent Grumusola imeetsia v Severnơ Aliaske. Pochva, bogatẩ montmorilloniticheskimi glinami imeet mikrorel'ef gil-ger (dyneobraznyI rel'ef) i osobenno tverdữ mineralogicheskưu poverkhnost'. Uchityvâa, chto promerzanie âvlâetsâ sushchestvennym vysushivâushchim protsessom protekâushchim na ètikh uchastkakh po kralnel mere raz $\mathrm{v}$ god, i chto isparenie prevyshaet osadki, genesis ètol pochvy predstavliâetsia pokhozhim na Grumusol teplogo i umerennogo klimatov. Darutsia khimicheskie i fizicheskie dannye.

$\mathbf{P}$ RESCOTT (1931) introduced the Australian aboriginal word gilgai into soil science to indicate certain regular forms of microrelief resultant from alternate wetting and drying of soil materials with a high clay content. Simpson (1934), Woolvorton (1936), Kreshna and Permul (1948), Hallingsworth et al. (1955), White and Bonestell (1960), and White (1962) subsequently presented works on the distribution, classification, and genetic dynamics of gilgai. Gilgai microrelief has been shown to require certain well-defined climatic conditions including a sufficient evaporation potential to allow the cracking properties of the soil to be expressed. Gilgai has been identified on many soils and over a wide range of climates within warm-temperate and tropical regions, but Costin (1955) has called attention to essential similarities of gilgai conditions and certain patterned ground features in the alpine hemi-arctic. Oakes and Thorp (1950) proposed the Great Soil Group name Grumusol for dark clay soils developed under alternating wet and dry seasons with gilgai microrelief. Oakes and Thorp (1950) grouped under the term Grumusol all the dark clays of warm-temperate and tropical regions characterized by granular surface-soil structure, and swelling and shrinking associated with wetting and drying. This classification unit includes the Regur soils of India, the Black and Gray Clays

* Journal series paper of the New Jersey Agricultural Experiment Station, Rutgers: The State University of New Jersey.

** Department of Conservation and Economic Development, State of New Jersey.

$\uparrow$ Professor of Soils, Rutgers University, New Brunswick, New Jersey, U.S.A. 
of East Africa, the Black Earths of Australia and the Sub-tropics, the Tirs of North Africa, the Sans Sequiti of Central America, as well as other locally applied names.

The central concepts of the grumusolic soils are: 1) They are clay soils that crack to some depth upon desiccation; 2) Rewetting of the soil takes place at some depth beneath the surface from water flowing into the cracks more readily than it will penetrate the surface peds; 3) The expansion of the clays beneath the surface causes an upward movement of the soil volume.

The soil survey staff of the U.S. Department of Agriculture (1960) places grumusolic soils in the order of Vertisols. While the Grumusol-like soil described in this report in some respects meets the spirit of USDA definition, in others this is not the case. The criteria for Vertisols include the presence of slickensides and wedge-shaped macro-aggregates at depth, but due to the presence of permafrost and probably frost action these features are not present. The term Vertisol depicts tropical to temperate temperatures with hot-dry seasons being normal with air temperatures occasionally exceeding $100^{\circ} \mathrm{F}$., which of course is not the case in northern Alaska.

While the Grumusol has been identified within many climatic regions, its northern extension has remained unknown. This paper presents for the first time information on an arctic equivalent to the Grumusol in northern Alaska.

In 1961, it was noted by MacNamara that some unique soil areas near Umiat, Alaska, (c. $69^{\circ} 23 \mathrm{~N} ., 152^{\circ} 10 \mathrm{~W}$.) possessed pronounced gilgai microrelief, very sparse vegetation, and desiccation cracks of considerable width and depth underlying a surface mulch of mineral soil aggregates. Topographic positions occupied by many of these soil areas are ridge crests, convex interfluves, and escarpment areas that are normally associated with the arctic brown soil (Tedrow and Hill 1955). Invariably the grumusolic sites are associated with bentonitic shale bedrock exposures of the member of the Upper Cretaceous Colville group of sediments. Previous mention had been made of the occurrence of a unique soil on the bentonitic formations, but no pedological study had been carried out (Tedrow and Hill 1954).

Umiat, located in the Arctic Foothills, is about $100 \mathrm{~m}$. above sea level in the east-west trending section of the Colville Valley, and the sites where these studies were carried out are upwards of $100 \mathrm{~m}$. above the valley floor. U.S. Weather Bureau records indicate an average annual precipitation equivalent to about 6 inches $\left(15.24 \mathrm{~cm}\right.$.) of water with the mean temperature above $0^{\circ} \mathrm{C}$. only for the months of June, July, August, and September. Over 60 per cent of the annual precipitation occurs during these four months.

The plant communities present on the surrounding rolling uplands are normally Eriophorum tussock communities. Tundra soils are of areal predominance (Tedrow and Hill 1955).

Fig. 1 shows a typical site of the arctic equivalent of the Grumusol.

The surface horizon of 2 to $6 \mathrm{~cm}$. thickness consists of a mulch of discrete, very hard granules, about 3 to $5 \mathrm{~mm}$. in diameter, many faced and having angular vertices between faces. Individual granules are often agglomerated into 
Fig. 1. Arctic equivalent of the Grumusol near Umiat, Alaska.

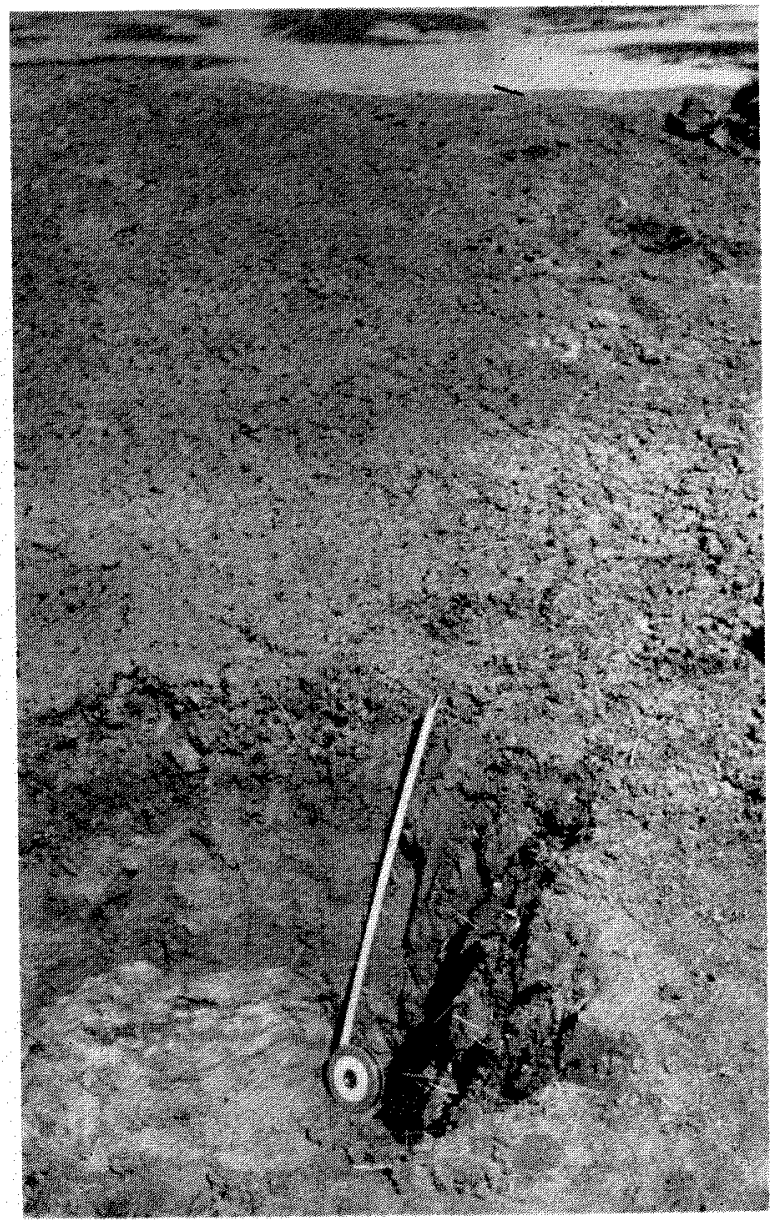

larger structural units near the surface. Desiccation cracks of 2 to $3 \mathrm{~cm}$. width and 8 to $20 \mathrm{~cm}$. depth are common when the surface is dry. Underlying the surface is a thick transition zone of aggregated soil materials of various blocky structures grading into a thick structureless viscous mass of clay which overlies permafrost. Pieces of grass and sedge roots, as well as recognizable blades and stems of grass and sedge, are attached to ped surfaces to a depth up to $20 \mathrm{~cm}$. A profile description from a representative site follows:

\section{Soil Profile Description}

Location: $31 \frac{1}{2}$ miles $(5.63 \mathrm{~km}$.). WNW of Umiat, Alaska (immediately above Red Hill).

Vegetation: Less than 10 per cent plant cover consisting of Carex sp. and Arctagrostis latifolia. 
Parent Material: Bentonitic shale of the Colville group.

Physiographic Position: Crest of a spur.

Topography: Flat, less than 2 per cent slope.

\begin{tabular}{ccl} 
Horizon & $\begin{array}{c}\text { Depth } \\
\text { cm. }\end{array}$ & \multicolumn{1}{c}{ Profile Characteristics } \\
I & $0-5$ & $\begin{array}{l}\text { Gray (N5/0 moist) clay; very hard, strong coarse to fine } \\
\text { granular aggregates; common finely divided white salt segre- } \\
\text { gations associated with exposed ped surfaces; lower boundary } \\
\text { transitional. }\end{array}$ \\
II & $5-30$ & $\begin{array}{l}\text { Very dark gray brown }(2.5 \mathrm{y} 3 / 2 \text { moist) clay; very coarse sub- } \\
\text { angular blocks structure separating to strong coarse granular } \\
\text { upon drying; lower boundary transitional. }\end{array}$ \\
III & $30-86$ & $\begin{array}{l}\text { Gray (N5/0 moist) clay; few fine yellowish brown (10YR5/6) } \\
\text { mottles; streaks of organic material; massive, very firm in } \\
\text { places; lower part water saturated; frost present at } 70 \mathrm{~cm} \text {; } \\
\text { lower boundary transitional. } \\
\text { Gray (N5/0 moist) thinly laminated shale, frozen (8 July } \\
\text { 1963). }\end{array}$ \\
IV & $86-125$
\end{tabular}
(Fig. 1).

The above site was sampled for moisture content 3 times during 1963

\section{Laboratory Investigations}

Bulk samples were taken for particle size distribution, organic matter content, cation exchange capacity, exchangeable cations, and $\mathrm{pH}$ determinations. Volumetric samples were taken in $8 \mathrm{~cm}$. increments by use of the Hvorslev soil sampler for moisture content, bulk density, determination of Atterberg limits and desiccation-contraction studies. Cation exchange capacity was determined by the method of Bower et al . (1952). The exchangeable calcium, sodium, and potassium were determined by flame photometric analysis of the ammonium acetate extracts and exchangeable magnesium by atomic absorption techniques. Mechanical analysis was by modification of the method of Kilmer and Alexander (1949). $\mathrm{pH}$ values were estimated in a 1:3 soil to water slurry. Organic matter was determined by wet combustion. Clay and salt composition were determined by X-ray diffraction.

\section{Discussion}

Soil $\mathrm{pH}$ values, organic matter content, water soluble cations, exchangeable cations, and related information are shown in Table I.

The clay fraction was predominantly 2:1 expanding lattice layered minerals with traces of clay-size quartz. The salt crust was identified as thenardite $\left(\mathrm{Na}_{2} \mathrm{SO}_{4}\right)$.

The presence of expanding lattice clays in the arctic equivalent to the Grumusol is brought out by X-ray diffraction studies, and is suggested by the high cation exchange capacity values which ranged as high as 147 me. per 
100 gms. of soil (Table I), and by general field observations. The authors are unable to give a satisfactory account for the erratic and anomalous values reported for cation exchange capacities (Table I). Even though the clay content is at a very high level throughout profile, horizons II and III had a noticeably soapy, dispersed feel while horizon I had a well-aggregated appearance. Horizon IV contained many bentonitic shale aggregates. Clays were not subdivided but had such a separation been made, horizons II and III may have yielded a more finely divided clay than horizons I and IV. It is possible that horizons I, II and III had at one time a finely divided clay present with subsequent ablatory effects from wind action removing the finest montmorillonitic clay fractions from horizon I, but this aspect of the problem was not investigated. This erratic distribution pattern of the cation exchange capacity with depth must be considered an open question. Considerable quantities of water soluble sodium and water soluble sulphate are present in the soil and large quantities of exchangeable sodium are also present. The large potential supply of these two ions naturally produces ideal conditions for the formation of thenardite, a very common constituent of salt crusts throughout arctic regions. Only small quantities of water soluble potassium, calcium, magnesium, and chlorides were present. After removal of the water soluble constituents, the soil showed about 13 per cent base saturation at the surface, which increased to some 61 per cent at depth. Whether these values can be ascribed to natural leaching processes is somewhat questionable because of the physical dynamics of the system. It is important to note the narrow $\mathrm{Ca}: \mathrm{Mg}$ ratios, particularly in the 5 to 15 and 15 to $30 \mathrm{~cm}$. depths. Throughout the arctic regions there appears to be a rather narrow exchangeable $\mathrm{Ca}: \mathrm{Mg}$ ratio compared to other climatic regions.

Table I shows that the $\mathrm{pH}$ values of the arctic equivalent of the Grumusol horizons varied between 4.1 and 4.8 , but after being leached free of sulphates the values showed a substantial increase.

Table I. Chemical properties of an arctic equivalent of the Grumusol.

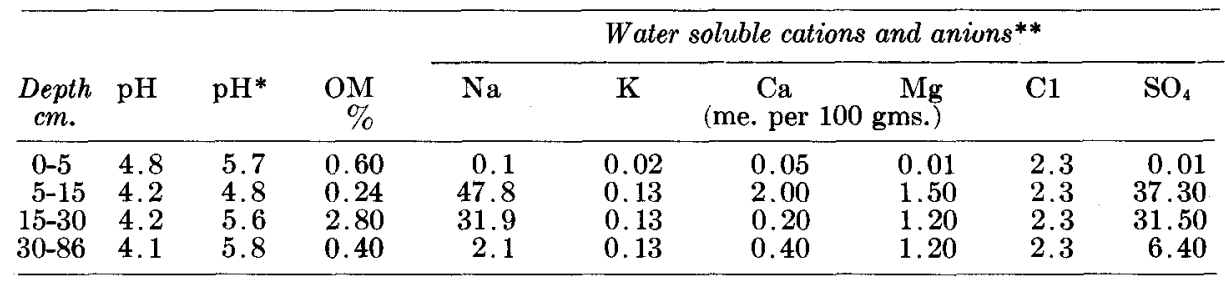

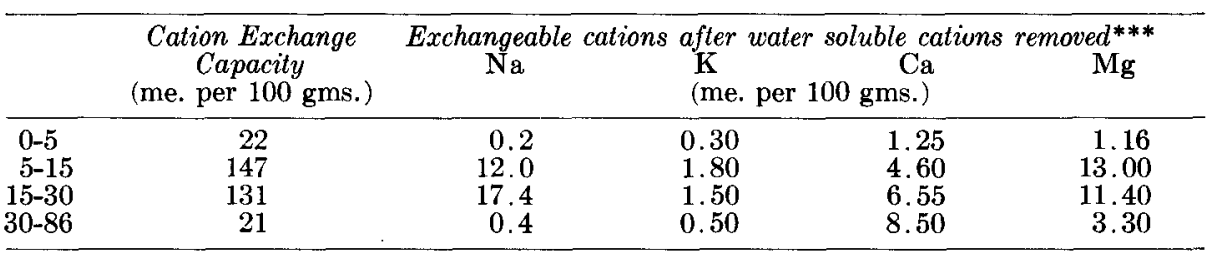

*After removal of water soluble salts (negative test for $\mathrm{SO}_{4}$ ).

**5 gm. sample leached with $250 \mathrm{ml}$. distilled water.

***5 $\mathrm{gm}$. sample leached twice (250 ml. $N$. NH $\left.\mathrm{NH}_{4} \mathrm{Ac}, \mathrm{pH} 7\right)$ with the difference between first and second leachings reported as exchangeable cations. 
The erratic distribution of the relatively undecomposed organic matter indicates the possibility that aggregates from the surface layer may have been incorporated into lower depths by falling or washing into the desiccation voids. The possibility of the extrusion of materials from below either by frost phenomena or swelling due to rewetting, however, must not be discounted. The self-mulching process of aggregates falling into voids has been discussed by Hallingsworth et al. (1955) and White and Bonestell (1960).

Table II contains certain physical parameters of the arctic Grumusol. Fig. 2 reveals the seasonal trend of moisture movement of this same soil. Measurements of the volumetric changes of the materials in the upper $10 \mathrm{~cm}$. indicate an average expansion coefficient of 1.76 from air dry to saturation.

Table II. Physical properties of an arctic equivalent of the Grumusol.

\begin{tabular}{cccccccc}
\hline & \multicolumn{2}{c}{ Atterberg Limits } & & & \multicolumn{3}{c}{ Particle Size Distribution } \\
Depth & \multicolumn{2}{c}{ \% S.M.C.* } & Bulk Density & Porosity & Very Fine Sand & Silt & Clay \\
cm. & Lower & Upper & g/ec & $\%$ & $\%$ & $\%$ & $\%$ \\
$0-5$ & 28 & 170 & 0.38 & 86 & 4 & 14 & 82 \\
$5-15$ & 34 & 198 & 0.85 & 69 & 4 & 16 & 80 \\
$15-30$ & 36 & 228 & 0.91 & 67 & 6 & 18 & 76 \\
$30-86$ & 36 & 218 & 1.01 & 63 & 5 & 22 & 76 \\
\hline
\end{tabular}

*Soil Moisture Content.

Sideri (1936), Lauritzen and Stewart (1941), Lauritzen (1948), and Templin et al. (1956), have discussed pore space and structural rearrangements that occur during soil volume change. Recently, White (1962) has discussed the volumetric changes and the construction of void space in grumusolic soils. Simpson 1934), as well as others, described the difficulties presented to construction and other engineering operations on soils of this character.

The presence of thenardite on some surface peds indicates that the structural aggregates at the surface are formed by desiccation processes. While it has been indicated that no great evaporation deficiency exists regionally within the main tundra belt, this does not apply to windswept exposures. Windswept surfaces that remain bare apparently possess large evaporation deficiencies. Field evidence indicates that grumusolic sites remain bare and are windswept throughout the year (Benson 1963).

Relatively large changes in the moisture regime of the surface of this site are indicated in Fig. 2. A volumetric change of the order of 22 per cent ( 57 per cent by weight) in one summer season is revealed. This is not the maximum magnitude of the change, for precipitation in excess of $0.25 \mathrm{~cm}$. occurred the day preceding the summer sampling.

Field observations together with soil moisture and porosity data indicate that the soil material between the $15 \mathrm{~cm}$. depth and the permafrost table exists essentially as a structureless plastic mass.

The general principles involving translocation and movement of mineral matter in the genesis of non-sorted circles have been discussed by Washburn (1956) and Corte (1963). Terzaghi and Peck (1948) indicate that a loose bentonitic clay's maximum total porosity in the structureless state is 84 per cent. In the arctic equivalent of the Grumusol, reduction in porosity with depth is attributed 
Fig. 2. Variation in soil moisture of arctic grumusol during summer of 1963; average of duplicated samples.

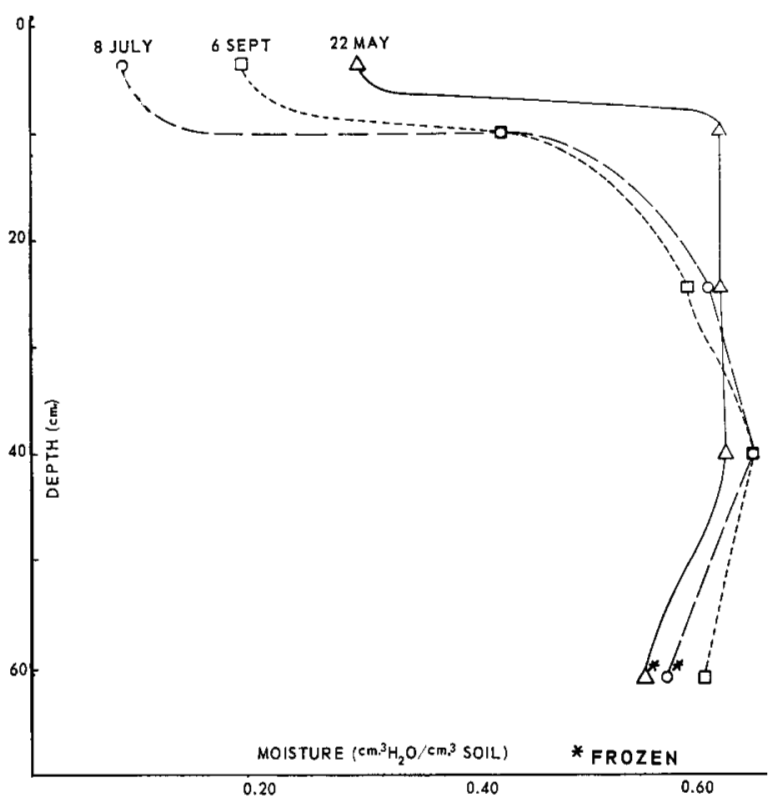

to packing without discernible orientation. With the advent of the winter season, the freezing of the included water will cause an expansion. The accompanying volumetric change should result in an upward compensatory soil movement.

Certain desiccation cracks extend to greater depths than others. The cracks present both zones of weakness for compensatory movements and loci of ice formation. Probably these cracks are widened by either ice lens growth or compensatory shifts.

\section{Summary}

Evidence has been presented to indicate the existence of grumusolic soil processes and conditions in the Arctic. These processes operate where soil materials present on stable landforms are high in expanding lattice clays of the montmorillonite group. Gilgai microrelief and the characteristic hard mulch surface of the grumusolic soils are produced. Considering freezing as being essentially a desiccating process operable at least once annually on these sites, and evaporation also causing considerable desiccation, the genesis of this soil is virtually identical with Grumusols of the temperate and warm climates.

\section{Acknowledgements}

These studies were aided by a contract between the Office of Naval Research, Department of the Navy, and the Arctic Institute of North America. Reproduction in whole or part permitted for any purpose by the United States Government. Appreciation is expressed to Professor S. J. Toth for certain chemical analyses. 


\section{References}

Benson, Carl, 1963. University of Alaska. Personal communication.

Bower, C. A., R. F. Reitemeier, and M. Fireman, 1952. Exchangeable cation analysis of saline and alkaline soils. Soil Sci. 73:251-67.

Corte, A. E., 1963. Particle sorting by repeated freezing and thawing. Sci. 142:499-501.

Costin, A. B., 1955. A note on gilgaies and frost soils. J. Soil Sci. 6:32-35.

Hallingsworth, E. G., G. K. Robertson, and F. R. Gibbon, 1955. Studies of pedogenesis in New South Wales: VII. The "gilgai" soils. J. Soil Sci. 6:1-31.

Kilmer, V. J. and L. T. Alexander, 1949. Methods of making mechanical analyses of soils. Soil Sci. 68:15-24.

Kreshna, P. G., and S. Permul, 1948. Structure in Black Cotton soils of the Nezamsagar Project Area, Hyderabad State, India. Soil Sci. 66:29-38.

Lauritzen, C. W., 1948. Apparent specific volume and shrinkage characteristics of soil material. Soil Sci. 65:155-79.

and A. J. Stewart, 1941. Soil-volume changes and accompanying moisture and pore relationships. Soil Sci. Soc. Amer. Proc. 6:113-16.

Oakes, H., and J. Thorp, 1950. Dark clay soils of warm regions variously called Rendzina, Black Cotton Soils, Regurs, and Tirs. Soil Sci. Soc. Amer. Proc. 15:347-54.

Prescott, J. A., 1931. The soils of Australia in relation to vegetation and climate. Commonwealth of Australia: Council for Scientific and Industrial Research Bull. 52:65-67.

Sideri, D. T., 1936. Soil Swelling: 1. The swelling of soil in water considered in connection with the problem of soil structure. Soil Sci. 41:135-51.

Simpson, W. E., 1934. Foundation experiences with clay in Texas. Civil Eng. 4:581-84.

Soil Survey Staff 1960. U.S.D.A. Soil Classification, a comprehensive system, 7th Approximation. U.S. Govt. Ptg. Office, Wash., D.C.

Tedrow, J. C. F., and D. E. Hill, 1954. Soil characteristics of the Arctic Slope of Alaska, a pedologic report. Boston Univ. Phys. Res. Lab. Unpublished manuscript. , 1955. Arctic brown soil. Soil Sci. 80:265-75.

Templin, E. H., I. C. Mowery, and G. W. Kunze, 1956. Houston black clay, the type grumusol: 1. Field morphology and geography. Soil Sci. Soc. Amer. Proc. 20:88-90.

Terzaghi, K., and R. B. Peck, 1948. Soil Mechanics in Engineering Practice. John Wiley and Sons.

U.S. Weather Bureau, Climatological data, Alaska, Annual Summaries. U.S. Department of Commerce.

Washburn, A. L., 1956. Classification of patterned ground and a review of suggested origins. Bul. Geo. Soc. Amer. 67:823-66.

White, E. M., 1962. Volume changes in some clay soils. Soil Sci. 94:168-72.

and R. G. Bonestell, 1960. Some gilgaied soils in South Dakota. Soil Sci. Soc. Amer. Proc. 24:305-9.

Woolvorton, D., 1936. A preliminary investigation into the subject of foundations in the "Black Cotton" and "Kyatti" soils of the Mandalay District, Burma. Proc. Intern. Conf. Soil Mech. 3:242-56. 